\title{
Usury, statutory avoidance and the Court of Chancery $1680-1800$
}

\author{
Dr Warren Swain and Karen Fairweather
}

$\mathrm{U}$ sury, when a borrower pays his lender the amount of the loan plus an additional sum as well, has caused problems for the law since the Middle Ages. In Canon Law and later common law, usury, any usury, was prohibited. By the sixteenth century the situation had changed. Usury was beginning to be seen as, if not exactly beneficial, then a fact of life in a rapidly developing economy. Providing that legal rates of interest were not exceeded, usury was permitted. By 1713 the rate of legal interest had fallen as low as five per cent. In these circumstances it is not perhaps surprising that, whilst some money lenders kept within the law, others did not. Escaping the statutory maximum rate of interest was simply a question of disguising the true nature of the transaction. Robert Ord, writing in the early nineteenth century, complained:

After a long contest between the usurer and the legislature, the ingenuity of the former hath prevailed over the authority of the latter; for the legislature have never yet been able to extirpate the practice of usurers, to get extravagant interest.

When Oliver Goldsmith observed that there is, "Scarce an Englishman who does not almost every day of his life, offend with impunity against some express law", he might almost have had the usurer in mind. Such was the state of things by 1820 that Robert Comyn was able to list 15 different types of loan transactions which fell outside the statute. Although judges, including Lord Hardwicke and Lord Mansfield, railed against evasion, they were hamstrung by the way in which usurious transactions were defined in law. Provided that the transaction involved a hazard, so that the lender was not certain to recoup his money, it was not within the legal definition of usury. Lord Mansfield made some efforts to stress substance over form but it was doubtful whether even this technique was effective in the face of a determined evader. Perhaps one device, the annuity for the life of the seller, more than any other came to encapsulate the problem by the mideighteenth century.

\section{ANNUITIES FOR THE LIFE OF THE SELLER: A STUDY IN AVOIDANCE}

Such was the popularity of the annuity for the life of the seller as a device for avoiding the statutory restrictions on usury that a Parliamentary Commission of the 1770s labelled it a "public nuisance." The concept was a simple one. A lender (the buyer) offered a borrower (the seller) a capital sum (the principal). In return the borrower undertook to pay a fixed sum of money per year (the annuity) for the rest of his life. The period taken to repay the principal (the years' purchase) was usually six years. Where the loan was riskier because the borrower was in poor health or lacked good security the years' purchase might be shorter. In a simple example, A (the borrower) sells an annuity of $£ 1,000$ a year for his own life to B (the lender) at six years' purchase. In return B pays A $£ 6,000$ as a capital sum. The lender's profit (or interest) came from the annual payments he hoped to receive after the elapse of six years.

The future Lord Chancellor, Thomas Erskine, called an annuity for the life of the seller a "scandalous contract", noting that "there is no honest trade so lucrative." The risk that the seller might die before the principal was repaid meant that the annuity for the life of the seller was outside the legal definition of usury. By insuring the life of the seller, buyers could protect themselves in the event of an early death.

Even when life insurance was used the transaction was not usurious. The appearance of a hazard was enough to take an annuity for the life of the seller outside usury. A Parliamentary Committee recommended regulating the prices at which the annuities could be sold, which would have meant that the lender's profit could not exceed the statutory maximum for usury. The Annuity Act of $1777 \mathrm{did}$ not incorporate such far reaching reform. Instead a scheme for registration of annuities was introduced which probably had a minimal impact on the scale of the trade. One writer described the statute as "useless." In the absence of effective statutory regulation and in place of a common law alternative, equity would play an important role in regulating loan transactions of all types. 


\section{THE DEMAND FOR LOANS AND EARLY EXAMPLES OF EQUITABLE RELIEF}

In the eighteenth century, as now, there were plenty of people who wanted to borrow money for a whole variety of reasons. High levels of borrowing amongst the aristocracy were not uncommon. The gaming mania of the early eighteenth century depleted many fortunes. The aristocracy also had greater access to consumer goods than ever before, which inevitably ate up capital. In an era of economic expansion businessmen were also borrowing significant sums. That some were forced to borrow at usurious rates can be explained, in part, by a private credit market that was weakened by a series of financial crises and growing government debt. The low levels of lawful interest may even have made the situation worse. With such small profit margins, some more respectable lenders were less willing to loan money in the absence of very good securities. Taken together this amounted to a major social problem which attracted a good deal of comment. One of these commentators, Daniel Defoe, in, The Complete English Tradesman, observed that, "the tragic stories of tradesmen undone by usury are so many and the variety so great."

If the loan fell outside the legal definition of usury there was little that the common law was willing to do unless there were other grounds to avoid the transaction such as fraud or illegality. The Court of Chancery was more likely to intervene. Hugh Bellot described the position before 1750:

\footnotetext{
The reports of cases... are very meagre, and it is difficult to ascertain whether they proceeded on any uniform principle; but it may be assumed that the policy of the Court of Chancery was to relieve against what were called catching bargains, which were transactions looked upon as evasions of the usury laws then in force and which transactions were very narrowly watched.
}

During this early period there was no consistent terminology let alone consistent application of clear legal rules. Equitable relief can only be described as a series of situations displaying some common characteristics. Many of the authorities were concerned with attempts to evade the usury laws and involved heirs.

Before the rise in popularity of the annuity for the life of the seller, another device was popular with those who wished to avoid the statutes on usury. A borrower approached a lender or an intermediary. The lender then agreed to sell the borrower goods at a grossly extravagant price on credit. In order to avoid problems of proof later on, a bond was usually used. The borrower sold the goods for less than he had agreed to pay. The lender's profit was the difference between the price paid by the borrower and the sum that he himself could have achieved for the goods had he sold them himself.

In Fairfax v Trigg ((1677) Rep Temp Finch, (1961) 79 Selden Society 448) Lord Nottingham was highly critical of these sorts of arrangements, ruling that, by way of relief, equity could reduce the sum owing to the "true and real" value of the goods sold. Chancery judges of this period were not very forthcoming about what in particular they disliked about such agreements. It may be that their actions were driven by a desire to prevent evasion of the usury laws, a dislike of sales at an exorbitant price, a desire to protect young heirs who often suffered from these transactions or a combination of all three.

Young heirs were also the victims of another method of avoiding usury, the post obit bond. In return for an immediate payment, the borrower promised that on the death of his father or other relative he would repay a much larger sum. Because the heir might die before he could actually inherit there was a hazard, taking the post-obit bond outside usury. Once again, Lord Nottingham was outspoken in his criticism. In 1680, (Anon (1680) unreported, (1961) 79 Selden Society 868), he thundered that, "this infamous kind of trade and circumvention ought by all means to be suppressed."

Not everyone shared Lord Nottingham's views. When the same litigation came before Lord Keeper North he dismissed the claim for relief despite calling it a "hazardous bargain” (Barny v Beak (1682) 2 Chan Cas 136). It needed a third hearing before Lord Jeffreys before Lord Nottingham's original decree was discharged (Berney v Pitt (1686) 2 Vern 14). In doing so Lord Jeffreys used the term "unconscionable" to describe the agreement. Batty v Lloyd ((1682) 1 Vern 142), another decision of Lord Keeper North, sheds some further light on his motives. In that case he made the point that those whose finances were in a poor state of repair should not be able to demand favourable terms. But the balance between lender and borrower was frequently struck in the borrower's favour. In Wiseman $v$ Beake ((1698) 2 Vern 121, 2 Freeman 111), the party seeking relief, a 40 year old proctor in Doctors' Commons, was about as far away from a typical young heir as it was possible to be. Yet he too secured relief. The tensions between these two positions would bubble to the surface all too frequently.

A third factual situation resembled the post obit bond but had even more serious consequences. It concerned an expectant heir urgently in need of ready cash who sold his expectancy and hence his future enjoyment of his estate at an undervalue. Perhaps not surprisingly, Lord Nottingham set such an agreement aside in Nott ${ }_{v}$ Hill ((1682) 2 Chan Cas 120). Lord Keeper North was not prepared to go as far in Batty $v$ Lloyd, but even he was unwilling to grant specific performance of an agreement when the heir refused to honour his bargain. In theory this position still left the plaintiff a remedy in law for straightforward breach of contract.

It is difficult to draw very firm conclusions from these early authorities. Examples of relief from a bad bargain are uncommon and there are counter examples. The greatest chance of success came when a bad bargain was combined with the sale of an expectancy, fraud or advantage taking. After 1750, a slightly clearer picture emerges with Lord 
Hardwicke's attempt to rationalise the grounds of equitable relief under the broad heading of fraud in Earl of Chesterfield v Janssen ( (1750) 2 Ves Sen 125, 1 Atk 301).

\section{STRUCTURING THE GROUNDS FOR EQUITABLE RELIEF AFTER 1750}

In a letter to his friend, Lord Kames, Lord Hardwicke would argue that 'fraud is infinite' and that 'no invariable rules can be established'. In these circumstances it seems likely that when, in Earl of Chesterfield $v$ Janssen, he set down five heads of fraud it was not his intention to limit relief to those who fell within one of his categories. In contrast, by the end of the century Lord Thurlow, in Fox $v$ Mackreth ((1788) 2 Bro Chan Cas 400), would explain that:

The Court will not correct a contract, merely because a man of nice honour would not have entered into it; it must fall within some definition of fraud; the rule must be drawn so as not to affect the general transactions of mankind.

The way in which Lord Hardwicke's words came to be accepted as a definitive statement is important for the way that relief in Chancery would come to be structured especially in the nineteenth century. The dominance of fraud also killed off the prospect of an overarching doctrine of unconscionability. Nevertheless, one category of equitable fraud in particular had the potential to offer relief in a wide variety of loan transactions. Lord Hardwicke identified that category as fraud which was, "apparent from the intrinsic nature and subject of the bargain itself; such as no man in his sense and not under delusion would make on the one hand and no honest and fair man would accept on the other."

The potential lay in the extent to which fraud of this sort could be used as a ground for refusing specific performance or setting aside an agreement or loan for an inadequate price. Although the earliest decisions are quite cautious, by the early 1740s Lord Hardwicke was suggesting that the position might have changed. Nevertheless, it is significant that these two decisions, Barnardiston v Lingood ( (1740) 2 Atk 133) and Buxton v Lister ( (1746) 3 Atk 383), involved an expectant heir and misrepresentation respectively. Matters reached a head in 1749, when in Underwood v Hitchcock ( (1749) 1 Ves Sen 279), Lord Hardwicke announced that specific performance might be refused solely on the basis of an inadequate price.

It is difficult to be sure about the extent to which Lord Hardwicke's approach meant that equity was more likely to refuse specific performance of annuities for the life of the seller. There are two reported cases. In one specific performance is granted and in the other refused (Lord

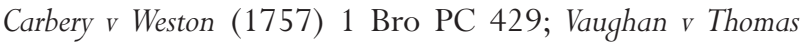
(1783) 1 Bro CC 556.) By the late 1780s things had moved on. By a clever sleight of hand, agreements (including loans) for an inadequate price came to be more closely regulated to the extent that agreements were set aside. In order to avoid the fear that every sort of hard bargain would be open to challenge in equity, Chancery judges began to allow an inadequate price to be presented as evidence of fraud. This allowed the change to be presented in traditional terms - whether or not there was a fraud. It also preserved a degree of flexibility. In nonmeritorious cases it was easy enough to rule that there was insufficient evidence of fraud. Many of the same results might easily have been reached under the existing rules because an inadequate price was usually combined with other kinds of wrongful behaviour.

In one class of case equity took a more interventionist line. Where the only evidence of fraud was an inadequate price the line between this position and the one where an agreement was set aside for inadequate price is wafer thin. In these circumstances in Heathcote v Paignon ( (1787) 1 Bro Chan Cas 1), which did not involve an heir and where there was expressly stated to be no evidence of distress, the agreement was set aside. For a short while, inadequacy of price in its own right remained a ground for refusing specific performance, but towards the turn of the century it came to be restricted to evidence of fraud. Although the rationale for relief had changed, the evidence is inconclusive in terms of whether relief was more or less likely than before. Where the transaction involved an heir on the other hand the courts began to move away from the paternalistic position which viewed all transactions with heirs with suspicion. After Gowland v De Faria ((1810) 17 Ves Jun 20), a decision which involved an annuity, this strict position was arguably relaxed. Henceforth, provided a fair price could be shown, then the transaction stood.

The extent to which equity intervened in loan transactions waxed and waned over time. There are too few reported authorities to come to definitive conclusions but it is evident that equity was not peripheral. Without Chancery, those who fell outside the legal definition of usury would certainly have been in a much worse position. In a sense, this was a golden age of equity as far as this sort of transaction was concerned. In the century that followed, equity would be restructured and even the statutory restrictions on usury removed. From an even longer perspective, some of the tensions evident in eighteenth century Chancery between protection of a borrower and freedom of contract are still very much alive.

Dr Warren Swain and Karen Fairweather

School of Law, Durham University 